\title{
Fair Play Behavior in Futsal: Study in High School Students
}

\author{
Ercan Zorba
}

Faculty of Sport Sciences, Muğla S1tkı Koçman University, Turkey

Copyright $\mathrm{O} 2018$ by authors, all rights reserved. Authors agree that this article remains permanently open access under the terms of the Creative Commons Attribution License 4.0 International License

\begin{abstract}
This study aimed to examine fair play behaviors of futsal players in high school regarding some variables. Totally 187 high school students including 76 males and 111 females participated in the study in 2017-2018 education period. The Fair Play Scale in Physical Education and Sport, developed by Hassandra et al. [7] and adapted to Turkish by Mirzaoglu [12] was used to collect data. The scale has four subscales including 16 items. The scale consists of the factors of respect towards teammates, cheating, respect conventions, and gamesmanship. The descriptive analysis of demographic variables and exploratory factor analysis for validity were used; Cronbach's alpha coefficient was calculated for reliability. The relationships were determined by using correlation analysis, and independent t-test was used for comparison between groups. Factor loadings ranged between 0,563 and 0,913. Moreover, Cronbach's alpha coefficient was found to be as 0,838 indicating that the scale had high reliability. In correlation results, the gender variable was only found to be significant $(\mathrm{p}<0,05)$ and negatively correlated $(\mathrm{r}=-, 144)$ in "gamesmanship." This result showed that boys are more prone to "gamesmanship" behaviors than girls. The only difference was found in "gamesmanship" when fair play behaviors of futsal athletes were compared according to genders $(p<0,05)$. This result showed that boys are more prone to "gamesmanship" behaviors than girls. The underlying reason for this may be that the sense of justice of boys is lower than the girls. Consequently, within the scope of the studies to create consciousness and realize required structural changes related to ethical values of sport, especially school physical education lessons and extramural competitions should be used as an environment to bring athletes in proper fair play behaviors. It is understood that fair play understanding can be achieved by facing students with problematic conditions in longer and continuous learning process, not with campaign, messages, sanction or transmission of plain moral theories.
\end{abstract}

Keywords High School, Futsal, Sports, Fair Play Behavior

\section{Introduction}

The relation between fair play and education is kinetic and dynamic structure. After fair play models that can be given in primary school terms in schools, the education should continue increasingly. The sports are the most influential factor in the continuity of the process. Fair play education can be given through sports ideally and efficiently. The sports have great importance regarding moral discipline; however, undesired results can occur unless paying attention. The sports make people interact because it is done with groups. This process works to develop the ethics of solidarity and cooperation. Notably, the individuals have been able to get this type of education in their early lives will apply this moral discipline in other activities of their lives. Sports are seen as practical tools to create social relations. Education has a central role in this field. Fair play, tolerance, and mutual respect, motivating individual responsibilities should be adopted in formal education [6].

The fair play behavior emphasizing the fair and honest play with its most straightforward meaning is expected from health and well-behaved individuals consisting health society. During the $20^{\text {th }}$ century, with the increment of commercial and political expectations from the sports, by pushing moral expectations into the background, the amateur spirit has decreased in value against professionalism. In addition to this, the increment of unethical behaviors in sports day by day has obligated the prior need of giving fair play insight in a long-term and systematical education process. As the result of this, the idea of primary and secondary school students should include in the studies related create a fair play culture by starting from the most basic levels gained importance [20].

The existing judgments in the society like "become absolutely a champion, win at all costs" prevent the occurrence of expectations in fair play understanding to come forward $[4,10]$. Furthermore, the problems in 
football in which the interest is experienced/ sustained intensively become more complicated. Although the fair play is desired in all sports, this concept is mostly violated in football [2]. When it is thought that all of the sporting rules are broken to win and get unearned income in soccer that children and youths have significant interests in, it remains as a central problem how to give children and teenagers, indirectly society, insights such as good, beautiful, truth, honesty, gentleness, understanding and tolerance, being virtuous. The interest of children and youths for football should not lead them to devastating results; they should be educated by including the practices leading to positive results in an educational manner. In this condition, it is an unavoidable fact that managers, coaches, athletes, and media have a critical duty, generally in sport and specifically in football. Since the early ages, fair play concept should be internalized and carried into effect as an inner code [14]. In this regard, this study aimed to examine fair play behaviors of futsal players in high school regarding some variables.

\section{Materials and Methods}

\subsection{The Population and the Sample}

While the high school students competing in futsal tournaments consisted of the population, the high school students participated in extramural futsal semi-finals organized by Turkish School Sports Federation in Muğla and Adana. A simple sampling method was used in this study and totally 187 high school students including 76 males and 111 females involved in 2017-2018 education period.

\subsection{Data Collection Tool}

The Fair Play Scale in Physical Education and Sport, developed by Hassandra et al. [7] and adapted to Turkish by Mirzaoglu [12] was used to collect data. The scale has four subscales including 16 items. The scale consists of the factors of respect towards teammates, cheating, respect conventions, and gamesmanship. The scale is the Likert type $(1=$ Never, $2=$ Rarely, $3=$ Sometimes, $4=$ Often, $5=$ Always).

\subsection{Data Analysis}

The descriptive analysis of demographic variables and exploratory factor analysis for validity were used; Cronbach's alpha coefficient was calculated for reliability. The relationships were determined by using correlation analysis, and independent t-test was used for comparison between groups.

\section{Analysis and Results}

\subsection{Demographic Results}

Of the participants, there were 76 boys (40,6\%) and 111 girls $(59,4 \%)$. The age mean was found to be $14,54 \pm 0,55$. Athletes were in $9^{\text {th }}$ grade $(n=92,49,2 \%), 10^{\text {th }}$ grade $(n=89$, $47,6 \%)$, and $11^{\text {th }}$ grade $(n=6,3,2 \%)$.

\subsection{The Results Related to Validity and Reliability}

Kaiser-Meyer-Olkin $(\mathrm{KMO}=$ and Bartlett's Sphericity test showed that Fair Play Scale in Physical Education and Sport was proper for factor analysis $(\mathrm{KMO}=0,817$; $\left.\chi^{2}=1616,034 ; d f=105 ; P=0.000\right)$. Varimax rotation with principal component analysis revealed four sub-dimensions (respect towards teammates, cheating, respect conventions, and gamesmanship). These sub-dimensions were in keeping with original scale. Factor loadings ranged between 0,563 and 0,913 . Cronbach's alpha coefficient was found to be as 0,838 indicating that the scale had high reliability (Table 1 ).

\subsection{Correlation Analysis Results}

In correlation results, the gender variable was only found to be significant $(\mathrm{p}<0,05)$ and negatively correlated $(\mathrm{r}=-, 144)$ in "gamesmanship." This result showed that boys are more prone to "gamesmanship" behaviors than girls (Table 2).

\subsection{The Gender Comparison of Fair Play Behaviors}

The only difference was found in "gamesmanship" when fair play behaviors of futsal athletes were compared according to genders $(p<0,05)$. This result showed that boys are more prone to "gamesmanship" behaviors than girls. The underlying reason for this may be that the sense of justice of boys is lower than the girls (Table 3).

\section{Discussion}

The studies examining the factors affecting athletes' performance has been conducted recently, and the results of these studies revealed that educational and psychological status of athletes is essential factors with their physiological features. In this regard, the importance of fair play has been emphasized by examining athlete and education psychology. Beyond any doubt, increasing unethical behaviors in sport influenced school physical education and sports, especially after the $70 \mathrm{~s}$, it was understood that behaviors related to fair play were not guaranteed adequately in the frame of socialization intention of physical education lessons [3]. This means that the opportunity to realize fair play education over 
developing rule conscious are not used or given enough importance. Kaehler [8], stating that the increment of improper behaviors unfitting to fair play in school sports was challenging, in the study examining moral education in physical education lesson, said that the students were not motivated for fair play, did not have knowledge and experiences related to fair play concept, prided on winning even by violating game rules and fair play principles. Absolute and objective performance is not the preeminent principle in modern school sports [13].
The studies showed that sports clubs had the critical role in learning unethical behaviors in sports for students who did not gain fair play understanding in physical education lessons. A study into determining fair play understandings of informal fair play of amateur football players consisted of the categories of juniors, youngsters, B-youth and A-youth and secondary school teenagers displayed the prevalence of the understanding "winning at all costs" among children and youths in school sports clubs.

Table 1. The validity and reliability results

\begin{tabular}{|c|c|c|c|c|}
\hline Items & RC & $\mathbf{C}$ & $\mathbf{G}$ & RTM \\
\hline 8. I shake my opponents' hands when the game finishes & 913 & & & \\
\hline 6. I shake my opponents' hands no matter I win or lose. & ,906 & & & \\
\hline 5. I congratulate my opponents when I lose the game. &, 853 & & & \\
\hline 7. I congratulate my teammates on their good performance. & ,768 & & & \\
\hline 14. I cheat. & & 893 & & \\
\hline 15. I cheat if it helps me win. & & 863 & & \\
\hline 13. I cheat if I am sure that I am not got caught. & &, 801 & & \\
\hline 11. I try to demoralize my opponents. & & & 880 & \\
\hline 9. I try to disturb my opponents. & & & 859 & \\
\hline 12. I try to get my opponents angry. & & & 847 & \\
\hline 10. I swear to my opponents. & & &, 561 & \\
\hline 1. I support my teammates & & & & 809 \\
\hline 2. I help my teammates. . & & & & ,771 \\
\hline 4. I stand by my teammates. & & & & 665 \\
\hline \multirow[t]{4}{*}{ 3. I reward my teammates' good efforts. } & & & & 657 \\
\hline & 20,808 & 18,540 & 18,489 & 14,971 \\
\hline & 20,808 & 39,348 & 57,836 & 72,808 \\
\hline & ,610 & ,895 & ,873 & ,888 \\
\hline
\end{tabular}

RTM=Respect for Team Mates, $\mathrm{RC}=$ Respect for Conventions, $\mathrm{G}=$ Gamesmanship, $\mathrm{C}=$ Cheating

Table 2. Correlation analysis results

\begin{tabular}{|c|c|c|c|c|c|c|c|}
\hline Variables & 1 & 2 & 3 & 4 & 5 & 6 & 7 \\
\hline $1 \mathrm{Age}$ & 1 & & & & & & \\
\hline 2 Grade &, $983^{* *}$ & 1 & & & & & \\
\hline 3 Gender &,- 078 &,- 077 & 1 & & & & \\
\hline 4 Respect for teammates &,- 061 &,- 069 & 084 & 1 & & & \\
\hline 5 Respect for Convention &,- 117 &,- 138 &,- 087 &, $227^{* *}$ & 1 & & \\
\hline 6 Gamesmanship &,- 008 &,- 024 &,$- 144^{*}$ & ,031 &, $219^{* *}$ & 1 & \\
\hline 7 Cheating &,- 030 &,- 029 &,- 124 & 011 &, $285^{* *}$ &, $574^{* *}$ & 1 \\
\hline 8 Fair play behavior &,- 072 &,- 089 &,- 132 &, $317^{* *}$ &, $636^{* *}$ &, $795^{* *}$ &, $788^{* *}$ \\
\hline
\end{tabular}

${ }^{*} P<0.05 ;{ }^{* *} P<0.01$ 
Table 3. The gender comparison of fair play behaviors

\begin{tabular}{lccccc}
\hline \multicolumn{1}{c}{ Variables } & Groups & $\mathbf{X}$ & SD & t & p \\
\hline Respect for Teammates & Boy & 4,59 &, 47 & $-1,142$ &, 255 \\
& Girl & 4,67 &, 50 & &, 235 \\
\hline Respect for Conventions & Boy & 4,54 &, 66 & 1,190 &, $050^{*}$ \\
& Girl & 4,40 &, 93 & & \\
\hline Gamesmanship & Boy & 3,91 &, 12 & 1,973 &, 092 \\
& Girl & 3,59 &, 09 & & \\
\hline Cheating & Boy & 4,67 &, 84 & 1,693 &, 071 \\
& Girl & 4,44 &, 99 & & \\
\hline Fair-Play Behavior & Boy & 4,43 &, 49 & & 1,817 \\
\end{tabular}

${ }^{*} P<0.05$

The study showed that amateurs saw the cases including informal fair play behaviors such as "helping referee to make a correct decision even it is contrary to one's benefit and judgment", "make an effort to remove a situation in which the opponent may be exposed" and "taking advantage of opponent's disadvantages" "unprofessional" and "sportsmanlike" in the near and high rates like professionals, and they stated that they would not act like this [21]. When this result is evaluated with the Pilz's study [15] showing that the young athletes having long time sporting club experiences saw the behaviors unfitting to fair play as tactical requirements, it is well understood that the way of fair play developing activities should direct to children and youths in primary and secondary school.

The priority that must be done in fair play education related to using school physical education is to determine in school sports what fair play is because of its versatility and the efforts to redefine. The concept of fair play restricted with the written rules is not satisfactory. Fair play phenomenon in school sports should have context beyond the rules. Within this scope, the definition of Gabler [15] including formal and informal fair play understandings together can be accepted as the reference point. Fair play shows its self in athletes' obeying the rules patiently, consistently and consciously under challenging conditions during competitions, not accepting to acquire illegally not to break equality of opportunity code, not attempting to take advantages of the opponent's disadvantages, seeing the opponents as partners and individuals who have that same rights allowing the game continues, not an enemy.

As the results of the analysis in this study examining the fair play behaviors of futsal players studying in high school, the boys displayed higher scores than girls regarding gamesmanship. Gümüş et al. [5] found that male students were more prone to toughness related to fair play than female students.

The only difference was found in "gamesmanship" when fair play behaviors of futsal athletes were compared according to genders $(p<0,05)$. This result showed that boys are more prone to "gamesmanship" behaviors than girls. The underlying reason for this may be that the sense of justice of boys is lower than the girls. No significant differences were found between genders regarding respect for teammates, respect for conventions, cheating, and fair play behavior.

In Topan's study [18], the students responded as "quite" in the sub-dimension of respect for the opponent. In the study of Balçıkanlı [1], football players stated that the items in respect for rules and officials defined them as "quite." In the study of Lemyre et al. [9] examining the relationship between high and low ego and sportspersonship orientation, the football players aged between 13-16 years defined themselves as "quite" in respect for rules and officials.

In the study of Miller et al. [11] young players responded as "quite," according to the results of Stornes and Ommundsen [17], handball players defined themselves as "quite" in respect for rules and officials. When we evaluate this sub-dimension in general, the behaviors of athletes aged between 12-15 years in respect for rules and officials are quite positive.

In the study of Lemyre et al. [9] examining the relationship between high and low ego and sportspersonship orientation, the football players aged between 13-16 years defined themselves as "relatively" in adjustment to social norms. In the study of Miller et al. [11], young players responded "quite" in adjustment to social norms. In the study of Stornes and Ommundsen [17], handball players defined themselves as "quite" in adjustment to social norms. In the study of Tsai and Fung [19], the mean scores of adjustment to social norms of young basketball players were examined, and this sub-dimension defined them as "relatively." When evaluated, it is thought that the athletes behave positively in adjustment to social norms. However, the importance and the results of the matches are the influential factors.

\section{Conclusions}

Consequently, even the futsal players participated in the study displayed fair play behaviors, they can move away from fair play behaviors during competitions. It is thought that the warnings and fines they face as the result of the negative attitudes and behaviors athletes display during 
competitions do not stem from negative and lacking fair play understanding but the state anxiety before the competition.

Within the scope of the studies to create consciousness and realize required structural changes related to ethical values of sport, especially school physical education lessons and extramural competitions should be used as an environment to bring athletes in proper fair play behaviors. It is understood that fair play understanding can be achieved by facing students with problematic conditions in more extended and continuous learning process, not with campaign, messages, sanction or transmission of plain moral theories.

As Orhun [13] stated, "developing solidarity and cooperation sense among children and youths, create a rule conscious, raising awareness about the influence and the functions of sports in human, environment nature and society with the humanitarian values such as sharing, justice, tolerance, and helpfulness are in the most important goals and principles." Physical education teacher can use the opportunities in physical education to make students face their value problems. The precondition for this is teachers having sufficient background. Teacher should determine the problems such as "winning at all costs," not control oneself," "not getting over the loss," "humiliating low skills," "setting up unequal teams," "inadequate cooperation," "misleading the truth," "putting the blame on someone else," "uncompromising behavior" and solve these through speech / talk, various dilemma stories, empathy, perspective taking and designed fair play games.

\section{REFERENCES}

[1] Balçıkanlı, G.S. (2009). Profesyonel Futbolcuların Fair playe Yönelik Davranışları ile Empatik Eğilim Düzeyleri Arasındaki İlişki, Gazi Üniversitesi Sağlık Bilimleri Enstitüsü, Ankara.

[2] Erzik, Ş. (2004) "Futbolun Rant1 250 Milyar Dolar", Cumhuriyet Gazetesi, 23 Ocak 2004.

[3] Gessmann, Rolf (1995) Fair Play - Eine wichtige Erziehungsaufgabe und ihre Umsetzung im Sportunterricht, Fairness und Fair Play, Hrsg.: Volker Gerhardt; Manfred Laemmer, 1. Aufl., Sankt Augustin: Academia-Verlag, s.138-155.

[4] Gökçe, A. (1991). "Sporda Erdemlik: Fair Play". Türk-Alman Kültür Diyaloğunda Spor Ahlakı ve Spor Felsefesine Yeni Yaklaşımlar, İstanbul: Maya Matbaacılık ve Yayıncilik.

[5] Gümüş, H., Saraçlı, S., Karakullukçu, Ö. F., Doğanay, G., \& Kurtipek, S. (2016). Ortaöğretim öğrencilerinde fair play kavram1. International Journal of Science Culture and Sport (IntJSCS), 4(2), 430-438.

[6] Güngör, E. (2010). Ahlak psikolojisi ve sosyal ahlak. Ötüken Neşriyat.
[7] Hassandra M, Goudas M, Hatzigeorgiadis A, Theodorakis Y (2002). Development of a questionnaire assessing fair play in elementary school physical education. Athlitiki Psychologia, 13:105-126.

[8] Kaehler, R. (1985). Moralerziehung im Sportunterricht. Untersuchung zur Regelpraxis und zum Regelbewusstsein. Frankfurt.

[9] Lemyre, P. N., Roberts, G. C., \& Ommundsen, Y. (2002). Achievement goal orientations, perceived ability, and sportspersonship in youth soccer. Journal of applied sport psychology, 14(2), 120-136.

[10] Loand, S. (2000) The Logic of Progress and the art of moderation in Competitive Sports", (Ed: Torbjörn Tannsjö and Claudio Tamburrini). Values in Sport. London \& New York: E \& FN Spon, p: 48.

[11] Miller Ronald F., Jarman Boyd. "Moral and ethical character development views from past leaders", Journal of PhysicalEducation, Recreation, and Dance, 59 (6), 1988, pp.72-78.

[12] Mirzaoglu, N. (2015). The validity and reliability of Turkish version of fair play questionnaire in Physical Education (FPQ-PE) and an implementation. Educational Research and Reviews, 10(17), 2469.

[13] Orhun, A. (1992) "Fair Play Okul Sporunda Bir Eaitim ilkesidir", Spor Bilimleri II. Ulusal Kongresi Bildirileri (20-22 Kasım 1992, Hacettepe Üniv., Ankara), Spor Bilimleri ve Teknolojisi Yay. No. 3, Ankara: Onlar Ajans, s. 186-188.

[14] Pehlivan, Z. (2004) Fair-Play Kavramının Geliştirilmesinde Okul Sporunun Yeri Ve Önemi.

[15] Pilz, G.A. (1995). "Zum Problem struktureller Bedingungen für Unfairness: Eine empirische Analyse", Fairness und Fair Play, Hrsg: Volker Gerhardt; Manfred Laemmer, 2. Aufl., Sankt Augustin: Academia-Verlag, s. 173-190.

[16] Pilz, G.A.; Wewer, W. (1987). Erfolg oder Fair Play? Sport als Spiegel der Gesellschaft. München: Copress Verlag.

[17] Stornes, T., \& Ommundsen, Y. (2004). Achievement goals, motivational climate and sportspersonship: a study of young handball players. Scandinavian Journal of Educational Research, 48(2), 205-221.

[18] Topan, A. (2011). Ortaöğretim Kurumlarında Okullar Arası Futbol Müsabakalarına Katılan Öğrencilerin Fair Play Anlayışlarının Kulüp Deneyimlerine Göre İncelenmesi, Gazi Üniversitesi Eğitim Bilimleri Enstitüsü, Ankara.

[19] Tsai, E., Fung, L. (2005) "Sportspersonship in youth basketball and volley ball players", Athletic insight, 7(2), pp. 37-46.

[20] Yıldıran, İ. (2005). Fair play eğitiminde beden eğitiminin rolü. Gazi Beden Eğitimi ve Spor Bilimleri Dergisi, 5(1), $3-16$.

[21] Y1ldıran, İ., \& Sezen, G. (2003). Beden eğitimi öğretmeni adaylarının sportmenlik ve profesyonellik arasında ikilem barındıran somut örnek olaylara yaklaşımlarının değerlendirilmesi. Gazi beden eğitimi ve spor bilimleri dergisi, 3 . 